\title{
A New Group (Type 3) of Mycobacterium celatum Isolated from AIDS Patients in the London Area
}

\author{
T. J. BULL, ${ }^{1 *}$ D. C. SHANSON ${ }^{1}$ L. C. ARCHARD, ${ }^{1}$ M. D. YATES,${ }^{2}$ M. E. HAMID,${ }^{3}$ AND D. E. MINNIKIN ${ }^{3}$ \\ Medical Microbiology Department, Charing Cross Hospital, London W6 $8 R F,{ }^{1}$ Regional Centre for Tuberculosis \\ Bacteriology, Public Health Laboratory, Dulwich Hospital, London SE22 8QF, ${ }^{2}$ and School of \\ Organic Chemistry, University of Newcastle-upon-Tyne, Newcastle, NE1 $7 R U,{ }^{3}$ England
}

\begin{abstract}
We describe a new group (type 3) of the recently proposed species Mycobacterium celatum isolated from eight patients with AIDS in London, England. Sequences of genes coding for 16S rRNA (EMBL accession no. Z46664) showed a divergence of 17 bases from $M$. celatum type 2 reference isolates and a divergence of 7 bases from $M$. celatum type 1 reference isolates. A reference strain is available (NCTC 12882).
\end{abstract}

Recent developments in the genetic identification and classification of bacteria by sequencing of the genes coding for $16 \mathrm{~S}$ rRNA (16S rDNA) (13) and other genes $(5,18)$ have yielded phylogenetically derived descriptions of a new group of isolates designated Mycobacterium celatum, within which type 1 and type 2 have been described (7). These organisms are similar, biochemically, to the Mycobacterium avium complex (MAC) (2), but they have unique species-specific $16 \mathrm{~S}$ rDNA sequences and superoxide dismutase sequences (5) that indicate that they are more closely related to Mycobacterium xenopi. The differentiation of this group is important therefore because these unique sequences are not detected by commercial genomic identification systems for MAC (4) and have caused some confusion because of the similarity of the $16 \mathrm{~S}$ rDNA sequence of Mycobacterium tuberculosis cross-reacting in some tests (3, $6,17)$. $M$. celatum has been reported as causing mycobacterial opportunistic infection in a small number of AIDS patients in the United States and Italy $(7,19)$ but not in the United Kingdom.

Fourteen isolates were recovered over a 2-year period from eight patients with AIDS in London, England, by standard clinical isolation methods (15). One isolate was obtained from a lesion on the thumb, and one was obtained from stool; the remainder were from induced sputum, blood culture, or bronchial washing samples. Four patients had multiple isolates, and disseminated infection was indicated in six patients.

Isolates were originally distinguished by their inability to react with the AccuProbe MAC (GenProbe, Inc., San Diego, Calif.) identification kit, but they appeared biochemically indistinct from MAC. Cells were acid-fast (as determined by auramine-phenol or Ziehl-Neelsen staining) coccobacilli and did not form spores, capsules, or aerial hyphae. Visible growth on Middlebrook $7 \mathrm{H} 10$ agar (9) from dilute inocula could be seen after 6 to 10 days. Colonies exhibited two forms designated rough and smooth, similar to those exhibited by $M$. avium (1). Colonies were initially transparent, but on prolonged culture they became creamy white and after 8 to 12 weeks they developed an intense yellow pigmentation independent of light. Growth occurred on Löwenstein-Jensen egg medium at $25,37,42$, and $44^{\circ} \mathrm{C}$. Further distinguishing characteristics included negative Tween hydrolysis, negative nitrate reductase reaction, and susceptibility to thiosemicarbazone (15

\footnotetext{
* Corresponding author. Mailing address: Medical Microbiology Department, Charing Cross Hospital, London W6 8RF, England. Phone: 081846 7299. Fax: 0818467261 . Electronic mail address: mbm100@ cxwms.ac.uk.
}

$\mu \mathrm{g} / \mathrm{ml}$ in Löwenstein-Jensen medium), but colonies showed an unusually high-level 14-day arylsulfatase reaction. All isolates were sensitive to streptomycin and ethambutol but resistant to isoniazid and rifampin as determined by the resistance ratio method (8). The majority of isolates (12 of 14) were also sensitive to ciprofloxacin $(5 \mu \mathrm{g} / \mathrm{ml}$ in Löwenstein-Jensen medium). All isolates exhibited reactions at levels below the cutoff (900 RLU) with the AccuProbe MAC identification kit. Weak false-positive reaction levels of 1,100 to 2,010 RLU were observed with AccuProbe MTB, by using a PAL (GenProbe, Inc.) luminometer, if the unbound probe hydrolysis incubation time was set at $5 \mathrm{~min}$ (GenProbe has subsequently recommended a 10-min hydrolysis time for all its kits). All isolates were negative with the Amplicor MTB (Roche Diagnostic Systems, Basel, Switzerland) PCR detection kit. Mycolic acid analysis of five representative isolates was performed by using protocols for thin-layer chromatographic analysis as previously described $(11,12)$, and the isolates were shown to have similar two-dimensional thin-layer chromatography patterns containing $\alpha$-mycolates, keto mycolates, and dicarboxylic mycolates characteristic of the MAC and $M$. celatum.

$16 \mathrm{~S}$ rDNA gene sequences $(1,494 \mathrm{bp})$ were determined by using primers and protocols as described previously (10). The relevant PCR products were isolated by agarose gel electrophoresis, excised by use of a scalpel, extracted with phenolchloroform-isoamyl alcohol, and concentrated by ethanol precipitation, and final concentrations for sequencing were estimated by a further agarose gel electrophoresis step. Automated sequencing of both strands, using $0.5 \mu \mathrm{g}$ of product DNA, was carried out with the PRISM (14) Taq dye termination system (Perkin-Elmer, Beckensfield, United Kingdom).

$16 \mathrm{~S}$ rDNA sequences obtained from $M$. celatum reference isolates (ATCC 51131 ${ }^{\mathrm{T}}$ and ATCC 51130) showed eight base discrepancies with published sequences (7) (EMBL accession no. L08169 and L08170), especially across known compression sites (Table 1). All 14 clinical isolates showed identical $16 \mathrm{~S}$ rDNA sequences which had the closest homology to the sequences derived from reference strains of $M$. celatum type 1 ( 7 base differences) and type 2 (17 base differences).

These data indicate a group of isolates which are similar to MAC in that they are able to produce prolonged disseminated infection in AIDS patients. They are also biochemically similar to MAC, differing only in that they are sensitive to streptomycin, ethambutol, and ciprofloxacin and are highly arylsulfatase positive.

There are no set guidelines, at the present time, governing the definition of mycobacterial species by using $16 \mathrm{~S}$ rDNA gene sequence data. Diversity within these genes has also been 
TABLE 1. Diversity among $16 \mathrm{~S}$ rDNA gene sequences obtained from $M$. celatum type 1 (ATCC $51131^{\mathrm{T}}$ ), M. celatum type 2 (ATCC 51130), and $M$. celatum type 3 (NCTC 12882) and EMBL sequences for $M$. celatum type 1 (L08169) and $M$. celatum type 2 (L08170)

\begin{tabular}{|c|c|c|c|c|c|c|c|c|c|c|c|c|c|c|c|c|c|c|c|c|c|c|c|}
\hline \multirow{2}{*}{ Sequence } & \multicolumn{23}{|c|}{ Nucleotide at base position ${ }^{a}$ : } \\
\hline & 41 & 42 & 43 & 44 & $44^{b}$ & $44^{b}$ & 45 & $45^{b}$ & 71 & 142 & 143 & 144 & 145 & 160 & $175^{b}$ & 380 & 415 & 417 & 425 & 426 & 428 & $1408^{b}$ & $1408^{h}$ \\
\hline L08169 & $\mathrm{T}$ & $\mathrm{T}$ & $\mathrm{T}$ & $\mathrm{X}$ & & & $\mathrm{G}$ & & $\mathrm{G}$ & $\mathrm{C}$ & A & $\mathrm{T}$ & $\mathrm{G}$ & $\mathrm{T}$ & & $\mathbf{T}$ & G & $\mathrm{C}$ & $\mathrm{C}$ & $\mathrm{G}$ & $\mathrm{T}$ & & \\
\hline L08170 & $\mathrm{T}$ & $\mathrm{T}$ & $\mathrm{T}$ & $\mathrm{X}$ & & & $\mathrm{G}$ & & $\mathrm{G}$ & $\mathrm{T}$ & $\mathrm{C}$ & $\mathrm{C}$ & A & $\mathrm{G}$ & & $\mathrm{T}$ & $\mathrm{T}$ & $\mathrm{G}$ & $\mathrm{T}$ & $\mathrm{C}$ & $\mathrm{G}$ & & \\
\hline Type 1 & $\mathrm{C}$ & $\mathrm{C}$ & $\mathrm{T}$ & $\mathrm{T}$ & $\mathrm{T}$ & $\mathrm{C}$ & $\mathrm{G}$ & & A & $\mathrm{C}$ & $\mathrm{A}$ & $\mathrm{T}$ & $\mathrm{G}$ & $\mathrm{T}$ & & $\mathrm{T}$ & G & $\mathrm{C}$ & $\mathrm{C}$ & $\mathrm{G}$ & $\mathrm{T}$ & & \\
\hline Type 2 & $\mathrm{C}$ & $\mathrm{C}$ & $\mathrm{T}$ & $\mathrm{T}$ & $\mathrm{T}$ & $\mathrm{C}$ & $\mathrm{G}$ & & A & $\mathrm{T}$ & $\mathrm{C}$ & $\mathrm{C}$ & A & $\mathrm{G}$ & & $\mathrm{T}$ & $\mathrm{T}$ & $\mathrm{G}$ & $\mathrm{T}$ & $\mathrm{C}$ & $\mathrm{G}$ & & \\
\hline Type 3 & $\mathrm{C}$ & $\mathrm{G}$ & $\mathrm{C}$ & $\mathrm{T}$ & $\mathrm{T}$ & $\mathrm{C}$ & $\mathrm{G}$ & $\mathrm{T}$ & A & $\mathrm{C}$ & A & $\mathrm{T}$ & $\mathrm{G}$ & $\mathrm{T}$ & $\mathrm{T}$ & $\mathrm{C}$ & $\mathrm{G}$ & $\mathrm{C}$ & $\mathrm{C}$ & $\mathrm{G}$ & $\mathrm{T}$ & $\mathrm{G}$ & $\mathrm{G}$ \\
\hline
\end{tabular}

“ Base positions correspond to those in M. tuberculosis 16S rRNA (EMBL accession no. X52917).

$b$ Inserted after this base position.
${ }^{b}$.

shown to be limited, when used in isolation, in differentiating closely related strains (16). The isolates described in this study most resemble $M$. celatum biochemically but show minor genetic differences from the two previously described reference strains. We suggest therefore that they should be classified as $M$. celatum type 3 .

Nucleotide sequence accession number. The $16 \mathrm{~S}$ rRNA sequence has been submitted to EMBL under accession no. Z46664, and a representative strain has been placed in the National Collection of Type Cultures, Colindale, London, United Kingdom, as $M$. celatum type 3 NCTC 12882.

\section{REFERENCES}

1. Belisle, J. T., and P. J. Brennan. 1994. Molecular basis of colony morphology in Mycobacterium avium. Res. Microbiol. 145:237-242.

2. Brander, E., E. Jantzen, R. Huttunen, A. Julkunen, and M.-L. Katilla. 1992. Characterization of a distinct group of slowly growing mycobacteria by biochemical tests and lipid analyses. J. Clin. Microbiol. 30:1972-1975.

3. Bull, T. J., and D. C. Shanson. 1992. Rapid misdiagnosis by Mycobacterium avium-intracellulare masquerading as tuberculosis in PCR/DNA probe tests. Lancet 340:1360.

4. Bull, T. J., and D. C. Shanson. 1992. Evaluation of a commercial chemiluminescent geneprobe system 'AccuProbe' for the rapid differentiation of mycobacteria, including 'MAICX', isolated from blood and other sites, from patients with AIDS. J. Hosp. Infect. 21:143-149.

5. Bull, T. J., D. C. Shanson, and L. C. Archard. 1995. Rapid identification of mycobacteria from AIDS patients by capillary electrophoretic profiling of amplified SOD gene. JCP Clin. Mol. Pathol. 3:M124-132.

6. Butler, W. R., S. P. O'Connor, M. A. Yakrus, and W. M. Gross. 1994. Cross-reactivity of genetic probe for detection of Mycobacterium tuberculosis with newly described species Mycobacterium celatum. J. Clin. Microbiol. 32:536-538.

7. Butler, W. R., S. P. O'Connor, M. A. Yakrus, R. W. Smithwick, B. B. Plikaytis, C. W. Moss, M. M. Floyd, C. L. Woodley, J. O. Kilburn, F. S.
Vadney, and W. M. Gross. 1993. Mycobacterium celatum sp. nov. Int. J. Syst. Bacteriol. 43:539-548.

8. Collins, C. H., J. M. Grange, and M. D. Yates. 1985. Organization and practice in tuberculosis bacteriology, p. 69-76. Butterworth, London.

9. Difco Laboratories. 1984. Difco manual, 10th ed. Difco Laboratories, Detroit.

10. Edwards, U., T. Rogall, H. Blöcker, M. Emde, and E. C. Böttger. 1989. Isolation and direct sequencing of entire genes. Characterization of a gene coding for 16S ribosomal RNA. Nucleic Acids Res. 17:7843-7853.

11. Minnikin, D. E. 1988. Isolation and purification of mycobacterial wall lipids, p. 125-135. In I. C. Hancock and I. C. Poxton (ed.), Bacterial cell surface techniques. John Wiley and Sons, Winchester, England.

12. Minnikin, D. E., I. G. Hutchinson, A. B. Caldicott, and M. Goodfellow. 1980. Thin-layer chromatography of methanolysates of mycolic acid-containing bacteria. J. Chromatogr. 188:221-233.

13. Rogall, T., T. Flohr, and E. C. Böttger. 1990. Differentiation of Mycobacterium species by direct sequencing of amplified DNA. J. Gen. Microbiol. 136:1915-1920.

14. Smith, L. M., J. Z. Saunders, R. J. Kaiser, P. Hughes, C. Dodd, C. R. Connell, C. Heiner, S. B. H. Kent, and L. Hood. 1986. Fluorescence detection in automated DNA analysis. Nature (London) 321:674-679.

15. Sommers, H. M., and R. C. Good. 1985. Mycobacterium, p. 216-248. In E. H. Lenette, A. Balows, W. J. Hausler, Jr., and H. J. Shadomy (ed.), Manual of clinical microbiology, 4th ed. American Society for Microbiology, Washington, D.C.

16. Stackebrandt, E., and B. M. Goebel. 1994. Taxonomic note: a place for DNA-DNA reassociation and $16 \mathrm{~S}$ rRNA sequence analysis in the present species definition in bacteriology. Int. J. Syst. Bacteriol. 44:846-849.

17. Stockman, L., B. Springer, E. C. Böttger, and G. D. Roberts. 1993. Mycobacterium tuberculosis nucleic acid probes for rapid diagnosis. Lancet 341: 1486.

18. Telenti, A., F. Marchesi, M. Balz, F. Bally, E. C. Böttger, and T. Bodmer. 1993. Rapid identification of mycobacteria to the species level by polymerase chain reaction and restriction enzyme analysis. J. Clin. Microbiol. 31:175-178.

19. Tortoli, E., C. Piersimoni, D. Bacosi, A. Bartoloni, F. Betti, L. Bono, C. Burrini, G. de Sio, C. Lacchini, A. Mantella, P. G. Orsi, V. Penati, M. T. Simonetti, and E. C. Böttger. 1995. Isolation of the newly described species Mycobacterium celatum from AIDS patients. J. Clin. Microbiol. 33:137-140. 